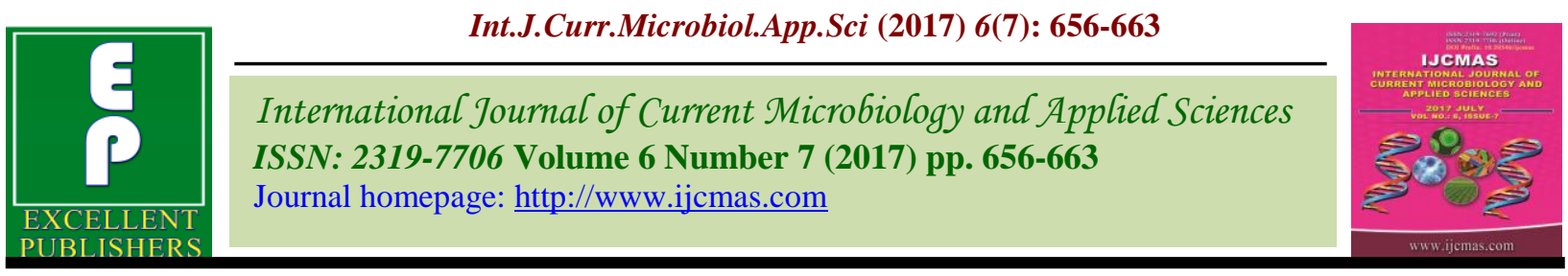

Original Research Article

https://doi.org/10.20546/ijcmas.2017.607.080

\title{
Analysis of Genetic Diversity of 12 Genotypes of Glycine max by Using RAPD Marker
}

\author{
Shashank A. Tidke', D. Ramakrishna ${ }^{1}$, S. Kiran ${ }^{1}$, Georgina Kosturkova ${ }^{2}$, \\ G.A. Ravishankar ${ }^{1}$ \\ ${ }^{1}$ Dr. C.D. Sagar Center for Life Sciences, Dayananda Sagar College of Engineering \\ (Visvesvaraya Technological University), Kumaraswamy Layout, Bangalore 560078, India \\ ${ }^{2}$ Bulgarian Academy of Sciences, Sofia, Bulgaria \\ *Corresponding author
}

\begin{tabular}{|c|c|}
\hline & B S T R A C T \\
\hline $\begin{array}{l}\text { Glycine max, } \\
\text { RAPD marker, } \\
\text { Unweighted pair } \\
\text { group method for } \\
\text { arithmetic mean } \\
\text { (UPGM), Genetic } \\
\text { diversity. }\end{array}$ & \multirow{3}{*}{$\begin{array}{l}\text { Soybean (Glycine max) is an essential legume crop in developing nations where it serves } \\
\text { to meet the increasing demands for protein, edible oil and calories. In this study, we } \\
\text { analysed genetic diversity of } 12 \text { soybean genotypes using Random Amplified Polymorphic } \\
\text { DNA (RAPD) molecular markers. A total of } 10 \text { RAPD primers were used for the screening } \\
\text { of } 12 \text { germplasm line out of which } 525 \text { fragments were amplified with } 10 \text { random primers } \\
\text { and } 74.85 \% \text { were polymorphic. Genetic similarity matrix based on Jaccard Similarity } \\
\text { Coefficients of soybean genotypes ranged from } 0.30 \text { to } 0.77 \text {. These coefficients were used } \\
\text { to construct a dendrogram using the unweighted pair group of arithmetic means } \\
\text { (UPGMA). All } 12 \text { soybean genotypes were grouped into six clusters. The largest cluster } \\
\text { consisted of } 5 \text { genotypes. The highest similarity among the soybean varieties were } \\
\text { observed between JS-02-21 and DSB-61 (0.756). Present study indicated a great deal of } \\
\text { germplasm diversity among these } 12 \text { genotypes. Our study revealed that RAPD technology } \\
\text { is potentially simple, rapid, reliable and an effective method of detecting polymorphism } \\
\text { for assessing genetic diversity between genotype and help in the selection of parent for } \\
\text { hybridization. }\end{array}$} \\
\hline Article Info & \\
\hline $\begin{array}{l}\text { Accepted: } \\
\text { 14 June } 2017 \\
\text { Available Online: } \\
10 \text { July } 2017\end{array}$ & \\
\hline
\end{tabular}

\section{Introduction}

Soybean (Glycine max) is an annual crop and belongs to the family of Fabaceae. It is an important legume crop, known for its high quality of protein and oil content, and beneficiary secondary metabolites such as saponin, phenolic compound, Isoflavone, (Sakthivelu et al., 2008). According to USDA data base total production of soybean in India is 11.50 million tons in 2016 while the world production of Soybean is 345.96 million metric tons in 2016/17. Martin et al., 2000 and $\mathrm{Fu}$ et al., 2006 have reported that the slight genetic base is a main limitation in breeding programs, due to the deficiency of genetic variability. Introducing new germplasm sources in breeding programs may provide the required genetic variability for the robust growth and variation of cultivars to biotic and abiotic factors.

Therefore, plant germplasm is a usual source to increase the current soybean genetic base (Chung and Singh, 2008). The genetic makeup of soybean provides a wide variety of 
uses, hence keeping it in high demand. Different kinds of markers were utilized for surveying hereditary variability of soybean genotypes-agronomic, morphological, biochemical attributes and molecular marker polymorphisms (Nelson, 2001; Giancola et al., 2002; Chowdhury et al., 2002; Ude et al., 2003; Dong et al., 2004; Bonato et al., 2006; Yamanaka et al., 2007; Malik et al., 2009; Goyal et al., 2012). All specified marker groups have constraints, however connected together they can give reliable data about analyzed germplasm (Sudaric et al., 2011). Smykal et al., (2008) have reported the quantitative and qualitative characters between varieties and utilized to identify genera and species to evaluate systematic connection. In plant with a narrow genetic base such as soybean, Priolli et al., (2002) have reported the morphological marker could not be sufficient for detection of differences between varieties.

In such case molecular marker can provide extra information of present diversity of germplasm. Subsequently they are extremely polymorphic and not affected by environmental conditions. Improvement has been made towards molecular markers progress in germplasm evaluation of diverse species. Li and Nelson (2001), Nikolic et al., (2004), Chen and Nelson (2005), Drinic et al., (2008) have reported RAPD markers can be effectively used for evaluation of genetic diversity because they can produce large data set. This type of DNA maker has been widely used in determination of genetic diversity of soybean genotypes. The genetic diversity of soybean cultivar has been carried out by the use of morphological, biochemical and molecular markers. Previous study reported on the selection of parents in the development of soybean cultivar (Devendra et al., 2015). In the present study we have conducted identification and analysis of genetic diversity of 12 soybean genotypes, based on polymorphic features and two and three dimensional Principal Component Analysis (PCA).

\section{Materials and Methods}

\section{Genotypes}

Twelve genotypes of soybean viz., MAUS, MACS, Bregg, JS335, JS-02-21, CO-3, CO-2, MACS-C1, DSB, RKS, Hardee, and DSB61were obtained from GKVK -UAS Bangalore.

\section{Explants preparation}

Seeds were surface disinfected with $70 \%$ ethanol for $2 \mathrm{~min}$, followed by $10 \mathrm{~min}$ in $5 \%$ sodium hypochlorite $(\mathrm{v} / \mathrm{v})$ treatment and then rinsed with sterile water for four to six times to remove the traces of sterilants.

\section{DNA Extraction and PCR analysis}

Genomic DNA was extracted from seeds of 12 different soybean genotypes using the SDS method (Doyle and Doyle, 1987). DNA was quantified by using spectrophotometer at $260 / 280 \mathrm{~nm}$. For quality assessment, DNA was electrophoresed on $0.8 \%$ agarose gel. The dilution of extracted DNA was verified again by spectrophotometery. A set of 10 Operon Technologies dreamer primer (Table 1) were used. PCR was performed in a thermal cycler

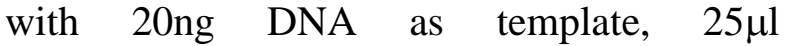
Amplification reaction contained $1 \mu \mathrm{l}$ of Taq DNA polymerase (Chromosome Biotech), 6.5 $\mu \mathrm{l}$ of 10X PCR buffer (Chromosome Biotech), $4 \mu \mathrm{l}$ of dNTPs (Chromosome Biotech), $1 \mu \mathrm{l}$ of $\mathrm{MgCl}_{2}$ (Qualigens), $1.0 \mu \mathrm{l}$ of Primer (Genei), $10.5 \mu \mathrm{l}$ of Nuclease free water, (Chromosome Biotech), $1.0 \mu \mathrm{l}$ of Template DNA. The DNA amplification protocol was $94^{\circ} \mathrm{C}$ for $3 \mathrm{~min}$, followed by 40 cycles of $94^{\circ} \mathrm{C}$ for $1 \mathrm{~min} 28^{\circ} \mathrm{C}$ for $1 \mathrm{~min}$, $72^{\circ} \mathrm{C}$ for $\min 2 \min$ and finally $72^{\circ} \mathrm{C}$ for 5 
min. The amplification products were stored at $4^{\circ} \mathrm{C}$ till electrophoresis was performed. At the time of electrophoresis and $3 \mu \mathrm{l}$ of $6 \mathrm{X}$ loading dye (GeNei, Bangalore) was added into PCR products. All amplification products were electrophoresed on $2 \%(\mathrm{w} / \mathrm{v})$ agarose gels at $60 \mathrm{~V}$ for 3 hours, stained with Ethidium bromide, The sizes of amplified fragments were determined using standard $100 \mathrm{bp}$ to $>1000$ bp DNA ladder mix (GeNei, Bangalore). Gel was photographed using a Gel documentation system (UVP MultiDocIt)

\section{Data scoring and analysis}

Amplification products in the gel images were scored for presence (1) or absence (0) missing and doubtful case were scored. Homology of bands based on the distance of migration of amplified DNA fragments according to their molecular weights in the gel was determined. Molecular weights of the bands were estimated using 100bp DNA ladder (Genei, Banglore) as standard. Jackard IJ Similarity Coefficients (F) was calculated using the programme SIMQUAL.

The similarity matrix was subjected to UPGMA (Unweighted pair group method for arithmetic mean) for cluster analysis and a dendrogram was generated (Sokal and Michener, 1958). These computations were performed using the programme NTSYS-pc version 2.0, Exeter software, New York (Rohlf, 1993).

The polymorphic percentage of obtaining band was calculated of by using the following formula.

$$
\text { Poly morphic Percents }(\%)=\frac{\text { Polymorphic Bands }}{\text { Total Bands }} \times 100
$$

\section{Result and Discussion}

Universal random primers viz., OPA1, OPA2, OPA3, OPA4, OPA5, OPA6, OPA7, OPA8, OPA9 and OPA10 were used for the study and they generated 525 RAPD amplification products among all 12 Soybean genotypes (Fig. 1-3). Among RAPD markers, OPA-1 produced the maximum number of bands including monomorphic and polymorphic bands (78). While RAPD marker OPA-5 generated a minimum number of bands (26) in the genomic pool. Polymorphic bands in screened markers ranged from 19 to 68 and the maximum was observed in OPA-2 (68) followed by OPA-7 (61) Level of monomorphic bands in screened markers as it was observed in OPA-1 (48), OPA-3 (12), OPA-4 (12), OPA-5 (12), OPA-2 (0), and OPA-7 (0) is given in table 2. The percent amplified bands in banding pattern was calculated and it was highest in OPA-2
(100\%) followed by OPA-7 (100\%) while the minimum was recorded from OPA-1 $(38.46 \%)$. (Table 2) Calculations for polymorphic information content (PIC) be completed using the formula of the expected heterozygosity (Smith et al., 2000) as: $\mathrm{PIC}=1$ $\sum \mathrm{f}^{2} \mathrm{i}$, where $\mathrm{f}$ is the percentage of genotypes in which the fragment is present. The PIC value is a sign of a high probability of obtaining polymorphism using that primer combination. Among Random amplified polymorphic DNA (RAPD) markers have more polymorphism information content (PIC) value among RAPD markers the highest PIC value was observed from OPA-9 (0.91) followed by OPA-1 (0.86). The minimum PIC value was observed from OPA-3 (0.69). (Table 2) The genetic relationship between soybean genotype was determined on the basis of Jackard IJ pair wise similarity coefficient values. The value of similarity coefficients ranged from 0.30 to 0.77 . 
Table.1 List of RAPD primers used in the diversity analysis of soybean

\begin{tabular}{|l|l|l|l|l|}
\hline Sr.no. & Primer & Sequence $\left(5^{\prime}>3^{\prime}\right)$ & $\begin{array}{l}\text { TM } \\
\left({ }^{\circ} \mathrm{C}\right)\end{array}$ & $\begin{array}{c}\text { GC Content } \\
(\%)\end{array}$ \\
\hline 1 & OPA-01 & CAGGCCCTTC & 34.0 & 70 \\
\hline 2 & OPA-02 & TGCCGAGCTG & 34.0 & 70 \\
\hline 3 & OPA-03 & AGTCAGCCAC & 32.0 & 60 \\
\hline 4 & OPA-04 & AATCGGGCTG & 32.0 & 60 \\
\hline 5 & OPA-05 & AGGGGTCTTG & 32.0 & 60 \\
\hline 6 & OPA-06 & GGTCCCTGAC & 34.0 & 70 \\
\hline 7 & OPA-07 & GAAACGGGTG & 32.0 & 60 \\
\hline 8 & OPA-08 & GTGACGTAGG & 32.0 & 60 \\
\hline 9 & OPA-09 & GGGTAACGCC & 34.0 & 70 \\
\hline 10 & OPA-10 & GTGATCGCAG & 32.0 & 60 \\
\hline
\end{tabular}

Source: GeNei Bangalore

Table.2 Characteristics of the amplification products obtained with 10 primers for RAPD

\begin{tabular}{|l|l|l|l|l|l|l|}
\hline Sr.no. & Primer & $\begin{array}{l}\text { Total } \\
\text { Bands }\end{array}$ & $\begin{array}{l}\text { Monomorphic } \\
\text { Bands }\end{array}$ & $\begin{array}{l}\text { Polymorphic } \\
\text { Bands }\end{array}$ & $\begin{array}{l}\text { Percent } \\
\text { polymorphism }\end{array}$ & PIC value \\
\hline 1 & OPA-01 & 78 & 48 & 30 & 38.46 & 0.86 \\
\hline 2 & OPA-02 & 68 & 0 & 68 & 100 & 0.83 \\
\hline 3 & OPA-03 & 31 & 12 & 19 & 61.29 & 0.69 \\
\hline 4 & OPA-04 & 56 & 12 & 44 & 78.57 & 0.85 \\
\hline 5 & OPA-05 & 26 & 12 & 14 & 53.84 & 0.74 \\
\hline 6 & OPA-06 & 41 & 12 & 29 & 70.73 & 0.77 \\
\hline 7 & OPA-07 & 61 & 0 & 61 & 100 & 0.86 \\
\hline 8 & OPA-08 & 58 & 12 & 46 & 79.31 & 0.85 \\
\hline 9 & OPA-09 & 51 & 12 & 39 & 76.47 & 0.91 \\
\hline 10 & OPA-10 & 55 & 12 & 43 & 78.18 & 0.85 \\
\hline & & $\begin{array}{l}\text { Total } \\
\text { Bands }= \\
\mathbf{5 2 5}\end{array}$ & $\begin{array}{l}\text { Total } \\
\text { Monomorphic } \\
\text { Bands }=\mathbf{1 3 2}\end{array}$ & $\begin{array}{l}\text { Total } \\
\text { Polymorphic } \\
\text { Bands }=\mathbf{3 9 3}\end{array}$ & & \\
& & & & & \\
\hline
\end{tabular}

Fig.1 RAPD banding pattern of twelve soybean genotypes using OPA-1 primers

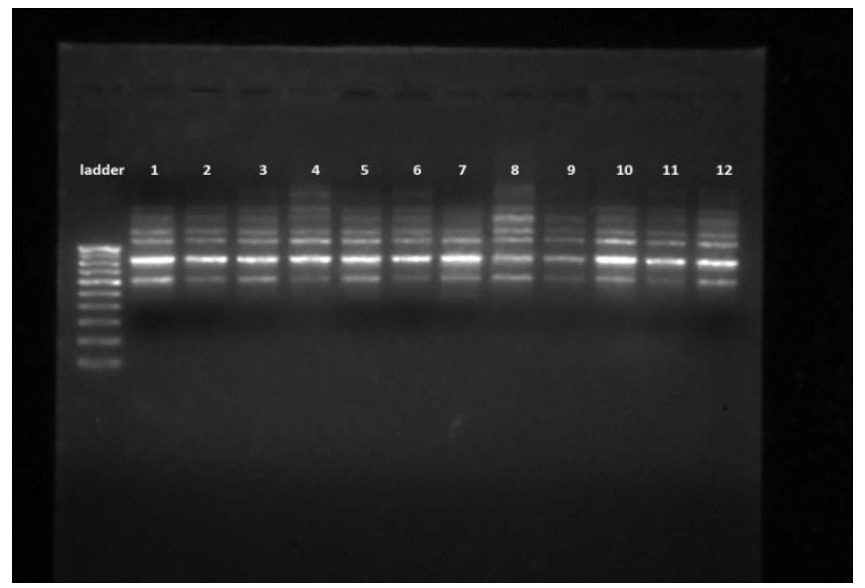


Fig.2 RAPD banding pattern of twelve soybean genotypes using OPA-4 primers

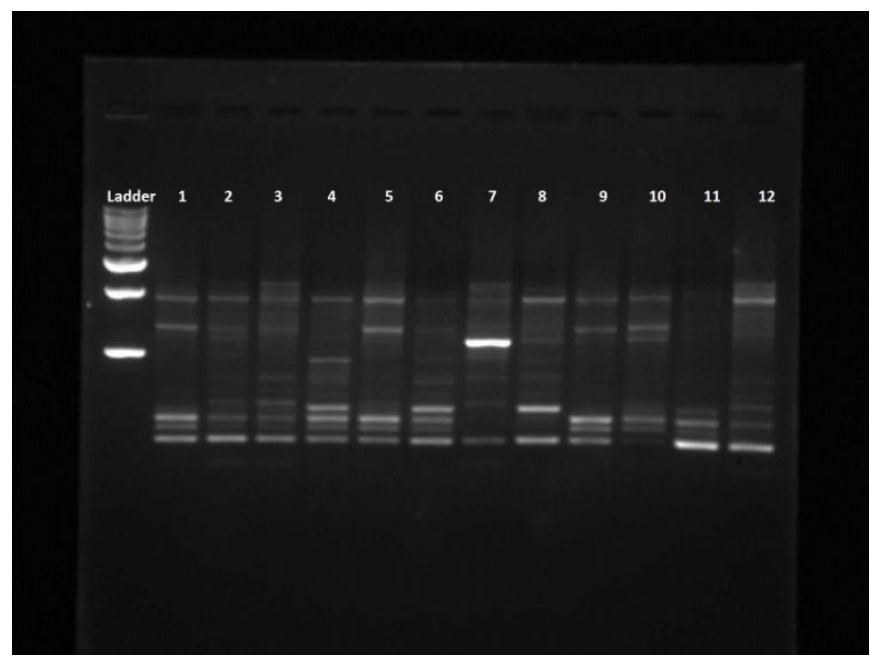

Fig.3 RAPD banding pattern of twelve soybean genotypes using OPA-2 primers

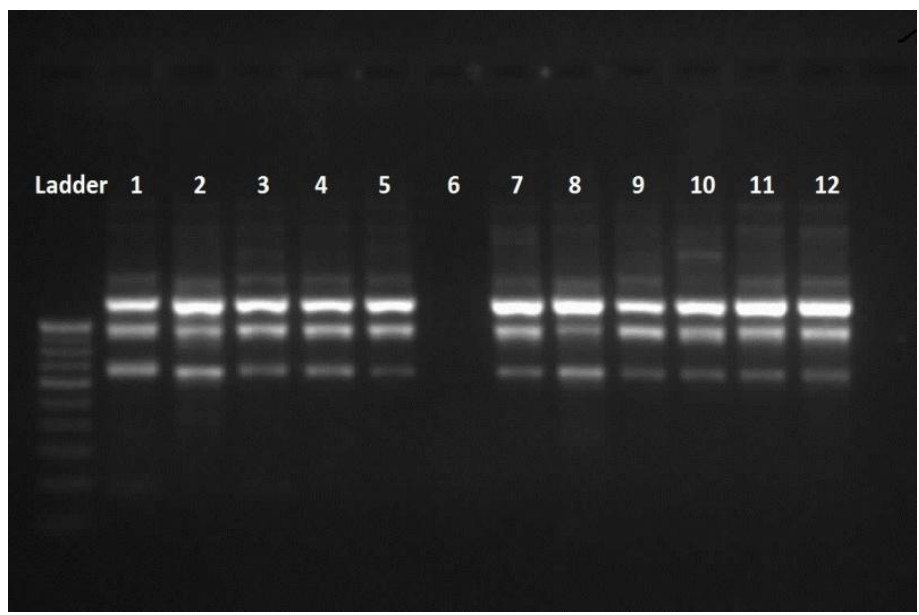

Fig.4 Dendrogram generated after RAPD analysis showing relationship among soybean genotypes used in this study

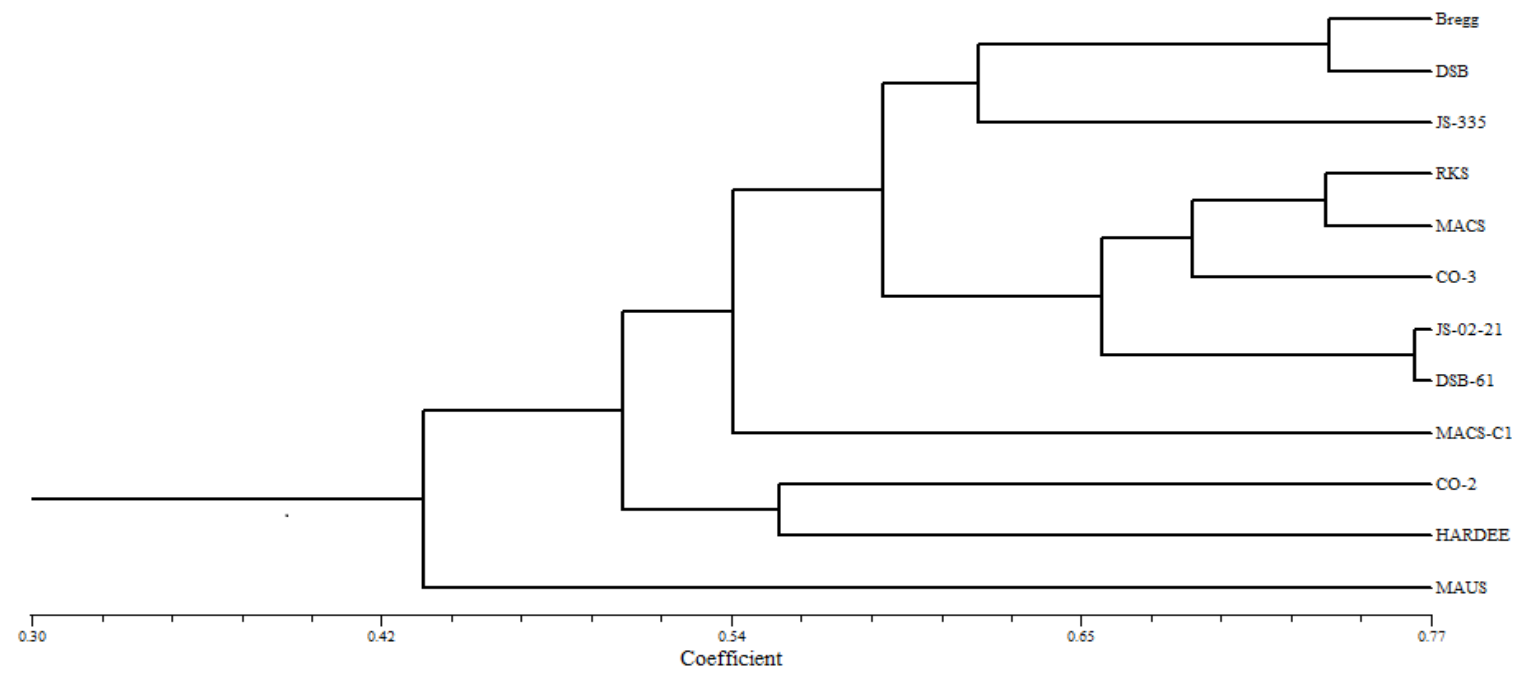


Fig.5 Two dimensional PCA scaling among soybean genotypes using RAPD data

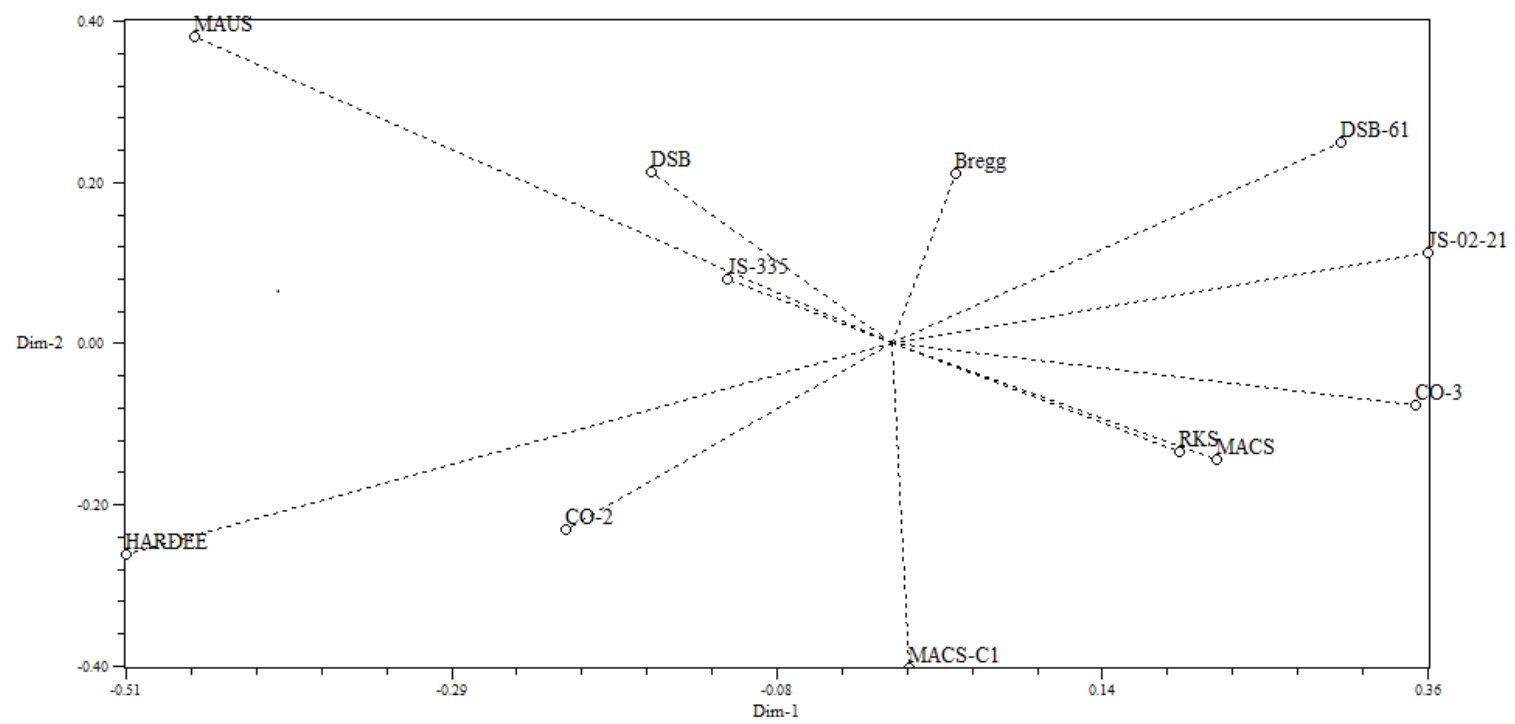

Fig.6 Three dimensional PCA among soybean genotypes using RAPD data

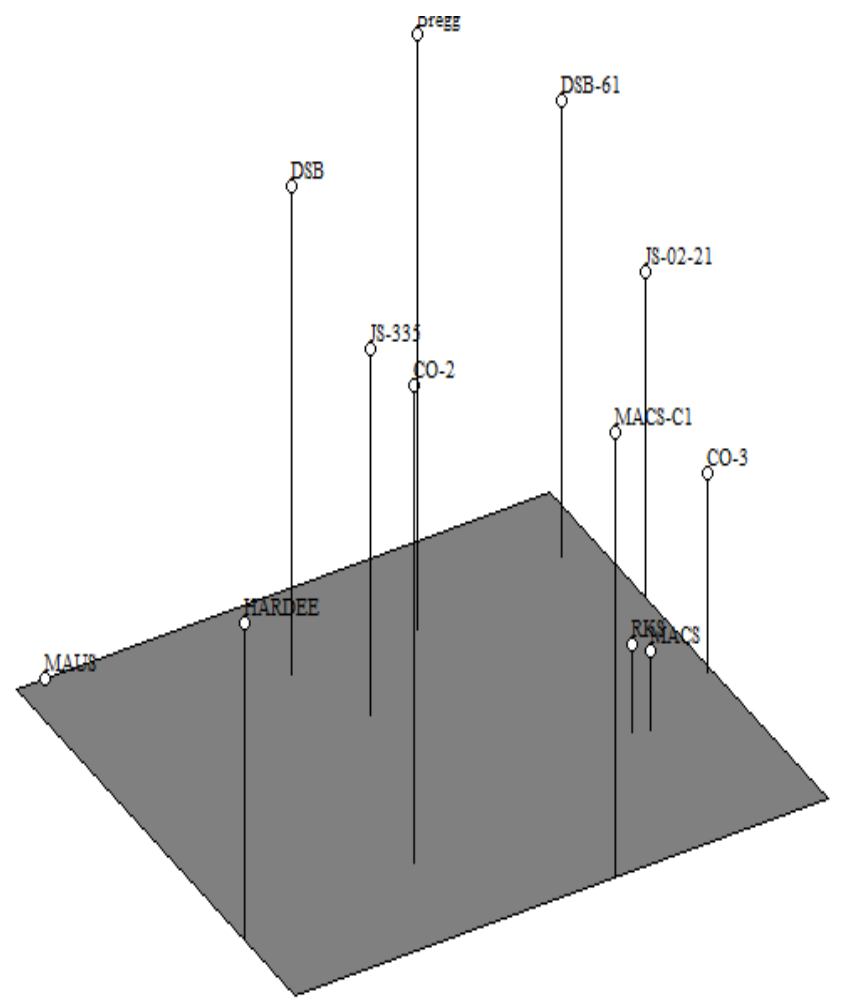

The Nei's similarity used to carry out the cluster analysis and to generate a dendrogram showing the relationships among the selected genotypes. All 12 genotypes were grouped into six clusters (Fig. 4). Second cluster is largest consist of 5 genotypes i.e. RKS, MACS, JS-02-21, CO-3 and DSB-61 The second largest cluster is the 1 st cluster which 
consists of 3 genotypes i.e. Bregg, DSB and JS-335 are closest. Then come $4^{\text {th }}$ cluster in which MACS-C1 and CO-2 are close then come $3^{\text {rd }}$ and $5^{\text {th }}$ are solitary clusters. The highest similarity among the soybean varieties were observed between JS-02-21 and DSB-61 (0.756).In two dimensional PCA (Fig. 5) MAUS and MACS-C1 were not grouped together in two dimensional and three dimensional PCA clustering (Fig. 6) while both these genotypes formed separate sub cluster in the dendrogram.

Devendra et al., (2015) studied the molecular characterization and genetic diversity assessment in soybean verities using SSR makers they have conclude that genetic similarity coefficient for the largely numbers of pairs was in the range 0.1-0.4 signifying high diversity between the chosen genotypes. All the 48 verities could be easily differentiate from each other's base on the selected markers. Shashank et al., (2014) studied the analysis of genetic diversity in 20 cotton germplasm line using RAPD markers. They have concluded that genetic similarity coefficient base on Jaccard similarity coefficient of cotton genotypes were ranging from $0.14-0.19$. All the 20 varieties could be easily distinguish from each other's. Dhirendra et al., (2013) reported the genetic diversity in soybean germplasm identified by RAPD markers. In this study they have used 30 RAPD primers for amplification and Out of these 259 loci, 253 loci were found to be polymorphic (97.68\%), concluded that RAPD methods could be used to investigate the genetic diversity of soybean germplasm. Present results depicted efficient use of RAPD technique to determine genetic distance among genotypes. It is therefore concluded that RAPD marker is potentially simple, rapid, reliable and effective method of detecting polymorphism for assessing genetic diversity between genotype and these help in the selection of parent for hybridization.

\section{Acknowledgement}

Authors are Thankful to Vice Chairman Dr. Premachandra Sagar for his keen support and encouragement. Further the financial assistance by Dayananda Sagar Institutions is gratefully acknowledged. GAR wishes to thank Department of Science and Technology, Government of India for financial support through competitive grant.

\section{References}

Antalina, S. 2000. Modern processing and utilization of legumes. Recent Research and Industrial achievement for soybean food in Japan. Proceeding of RILET-JIRCAS. Workshop on Soybean Research, September 28, Malang-Indonesia.

Balasubramaniyan, P., and S.P. Palaniappan. 2003. Principles and practices of agronomy. Pub. By agrbios (India). 1: 45-46.

Bonato, A.L., C.,S. Eberson, O.G., Isaias, C.A. Arias. 2006. Genetic similarity among soybean (Glycine max L. Merill.) Cultivars released in Brazil using RFLP markers. Genet. Mol. Biol., 29: 692-704.

Chen, Y., and R.L. Nelson. 2005. Relationship between Origin and Genetic Diversity in Chinese Soybean Germplasm, Crop Sci., 45: 1645-1653.

Chowdhury, A.K., P. Srinives, P. Tongpamnak, P. Saksoong, P. Chatwachirawong. 2002. Genetic relationship among exotic soybean introductions in Thailand: Consequence for varietal registration. Sci. Asia, 28: 227-239.

Chung, G., Singh, R.J. 2008. Broadening the genetic base of soybean: a multidisciplinary approach. Crit. Rev. Plant Sci., 27: 295-341.

Devendra, K., Chauhan, J.A., Bhat, A.K. Thakur, S. Kumari, Z. Hussain and C.T. Satyawrthi. 2015. Molecular characterization and genetic diversity assessment in soybean verities using SSR makers, Indian J. Biotechnol., 14: 504-510.

Dhirendra Khare, Aanchal Bisen, Priya Nair, Niraj Tripathi. 2013. Genetic diversity in soybean germplasm identified by RAPD markers, J. Mol. Biol. Biotechnol., 3: 121123. 
Dong, Y.S., L.M. Zhao, B. Liu, Z.W. Wang, Z.Q., Jin and H. Sun. 2004. The genetic diversity of cultivated soybean grown in China. Theor. Appl. Genet., 108: 931-936.

Doyle, J.J., Doyle, J.L. 1987. A rapid DNA isolation procedure for small quantities of fresh leaf tissue, Phytochem. Bull., 19: 1115.

Fu, Y.B. 2006. Impact of plant breeding on genetic diversity of agricultural crops: searching for molecular evidence. Plant Genetic Res., 4: 71-78.

Giancola, S.S., M. Poltri, P. Lacaze and H.E. Hopp. 2002. Feasibility of integration of molecular markers and morphological descriptors in a real case study of a plant variety protection system for soybean. Euphytica, 127: 95-113.

Goyal, R.S., Sharma and B.S. Gill. 2012. Variability in the nutrients, antinutrients and other bioactive compounds in soybean [Glycine $\max ($ L.) Merrill] genotypes. J. Food Legumes, 25: 314-320.

Li, Z., and R.L. Nelson. 2001. Genetic diversity among soybean accessions from three countries measured by RAPDS. Crop Sci., 41: 1337-1347.

Malik, F.A., M. Ashraf, A.S. Qureshi, M.R. Khan. 2011. Investigation and comparison of some morphological traits of the soybean populations using cluster analysis. Pak. J. Bot., 43: 1249-1255.

Martin, M.S. 2000. Crop strength through diversity. Nature, 406: 681-682.

Nikolic, A. 2005. Characterization of soybean genotypes using molecular-genetic methods. Master's thesis. University of Belgrade, Faculty of Biology, Belgrade, Serbia.
Priolli, R.H.G., C.T. Mendes, N.E. Arantes, E.P.B. Contel. 2002. Characterization of Brazilian soybean cultivars using microsatellite markers. Genet. Mol. Biol., 25: 185-193.

Rohlf, F.J. 1998. "NTSYS-PC Numerical Taxonomy and Multivariate Analysis System Version 2.1," Exeter Software, Applied Biostatistics, New York

Shashank Ashokrao Tidke, S. Kiran and Sanjay Ningappa Harke. 2014. Analysis of genetic diversity in 20 cotton germplam line using random amplified polymorphic DNA markers, Asian J. Plant Sci., 13: 184-189.

Smykal, P.J., Horacek, R. Dostalova, M. Hybl. 2008. Variety discrimination in pea (Pisum sativum L.) By molecular, biochemical and morphological markers. J. Appl. Genet., 49: 155-166.

Sudaric, A.M., Vrataric, I. Rajcan, T. Duvnjak, M. Volenik. 2008. Application of molecular markers in parental selection in soybean. Acta Agron. Hung, 56: 393-39.

Ude, G.N., W.J. Kenworthy, J.M. Costa, P.B. Cregan, J. Alvernaz. 2003. Genetic diversity of soybean cultivars from China, Japan, North America, and North American ancestral lines determined by Amplified Fragment Length Polymorphism. Crop Sci., 43: 1858-1867.

Yamanaka, N.H., Sato, Y. Zhenyu, H.X.U Dong, L.L. Catelli, E. Binneck, C.A.A. Arias, R.V. Abdelnoor. 2007. Genetic relationship between Chinese, Japanese and Brazilian soybean gene pools revealed by simple sequence repeat (SSR) markers. Genet. Mol. Biol., 30: 85-88.

\section{How to cite this article:}

Shashank A. Tidke, D. Ramakrishna, S. Kiran, Georgina Kosturkova, Ravishankar, G.A. 2017. Analysis of Genetic Diversity of 12 Genotypes of Glycine max by Using RAPD Marker. Int.J.Curr.Microbiol.App.Sci. 6(7): 656-663. doi: https://doi.org/10.20546/ijcmas.2017.607.080 